УДК 37.091.12

Габріела Папротна,

Доктор філософії

(Академія Ігнатіанум у м. Кракові, Республіка Польща) gabriela.paprotnaeignatianum.edu.pl

ORCID: 0000-0003-2330-1626

\title{
ПРОФЕСІЙНИЙ РОЗВИТОК УЧИТЕЛЯ
}

У статті представлено аналіз проблеми професійного розвитку вчителя. Професійна діяльність $\epsilon$ важливою частиною людського життя, яка дає змогу задовольнити багато потреб як духовних, так $i$ матеріальних. Професійний розвиток - ие процес кількісних і якісних змін, котрі дозволяють наблизитися до досконалої діяльності в певній галузі. Цей процес є однаково зумовлюваний як суб'єктивними, так і об'єктивними чинниками.

На підставі проведеного аналізу обтрунтовано, щуо професійний розвиток проявляється в таких формах активності, як: соиіально-професійна адаптація, сочіально-професійна ідентифікачія, соиіальнопрофесійна стабілізація, перепідготовка й самопідготовка, соиіально-професійне вдосконалення, сочіально-професійні успіхи, поступовий регрес соиіально-професійної активності, вихід із чинної сочіально-професійної діяльності, професійна ремінісценція та рефлексія.

Доведено, щчо професійний розвиток є такою категорією розвитку вчителя, яка иілком охоплює його індивідуальність. Водночас професійний досвід зумовлює також функиіонування вчителя в різних сферах позапрофесійного життя. У цуьому контексті він стає об'єктом різноманітних досліджень, в основному професіології.

Ключові слова: учитель, професійний розвиток, професійна діяльність, професійне зростання.

1. Вступ. Професійна діяльність $\epsilon$ істотною частиною людського життя й займає важливе місце в активності людини. Завдяки їй людина розвиває свої здібності, здобуває засоби для існування, має відчуття сенсу життя. Праця дає змогу задовольнити багато потреб як духовних, так і матеріальних.

Нинішні умови суспільного життя показують, яким цінним "товаром" стала робота, як легко її можна втратити і як важко ії здобути, а також як багато негативних наслідків спричиняє її відсутність.

Про значимість професії свідчить і те, що почала виділятися галузь знань, яка розглядає умови, процес, результати й закономірності професійного розвитку, тобто професіологія ${ }^{1}$. Досліджуючи явища, пов'язані загалом із професійною роботою, вона використовує дані багатьох інших наук, зокрема психології, соціології, історії, педагогіки, філософії, етнології, анатомії та фізіології. Знання, отримані в ході професіологічних досліджень, мають як теоретичну (описують певний фрагмент дійсності) цінність, так і практичну, таку, що служить удосконаленню професійної роботи на кожному іiі етапі, від підготовки аж до виходу з неї.

Метою професіології $є$ проведення досліджень над професійним розвитком, його пропагування, розробка методів, технік і пізнавальних засобів у цій сфері, формування відповідного ставлення особистості й суспільства до можливості й перспектив професійного розвитку, також мотивування до участі в професійному громадському житті. Щоб досягнення вказаних вище цілей стало можливим, професіологія надає знання про професійний розвиток, пояснює його закономірності й зумовленість, виявляє можливості такого розвитку в контексті специфічних потреб особистості, вказує на можливості й засоби пізнання та стимулювання процесу професійного розвитку.

Важливим завданням цієї галузі є популяризація професіологічних знань серед різних соціальних груп, а також створення теоретичного підгрунтя для професіології як науки про професійний розвиток людини ${ }^{2}$

2. Поняття професійного розвитку у світлі теорії місця і простору Казимира Чарнецького.

Різні теорії тлумачили процес професійного розвитку. Одна з них - динамічна - це теорія місця й простору, авторство якої належить К. Чарнецькому. За положеннями цієї концепції людина в окремих ситуаціях, отже і в професійній діяльності, займає окреслений простір і місце в співвідношеннях індивідуального й групового життя. Місце й простір змінюються разом із розвитком, зростанням та займаним соціальним статусом. Місце й простір змінюються, тому що є результатом динаміки технічноекономічного розвитку. Мають на них вплив також індивідуальні властивості особистості та зв'язки, що виникають між індивідом та реальною дійсністю ${ }^{3}$.

\footnotetext{
${ }^{1}$ K. Czarnecki, S. Karaś, Profesjologia w zarysie (rozwój zawodowy człowieka), Radom 1996.

${ }^{2}$ K. Czarnecki, S. Karaś, Profesjologia w zarysie (rozwój zawodowy człowieka), dz. cyt., s. 12-14.

${ }^{3}$ K. Czarnecki, Rozwój zawodowy człowieka, Warszawa 1985, s. 53-59.
} 
Професія людини визначає її місце в суспільному розподілі праці. Це місце людина займає завдяки своїй свідомій і доцільній професійній активності. У займаних по черзі місцях і просторах людина формує свою індивідуальність. Відносно постійні місця й простори дають відчуття безпеки (суспільної, економічної, розвитку), а також оригінальності, індивідуальності й особистої цінності. Ці місця й простори є невід'ємним атрибутом життя людини, їі розвитку, діяльності, заразом і успіхів та життєвих і професійних невдач. У випадку, коли людина займає місця й простори, невідповідні своїм вимогам і прагненням, вона вживає заходи щодо їх зміни ${ }^{4}$.

У руслі визначених засад потрібно розуміти професійний розвиток як явище, яке має свій початок, процес кількісних і якісних змін, також і кінець, що виникає через припинення професійної діяльності на схилі життя. Розгляньмо поняття ширше - професійний розвиток є "процесом змін, що відбуваються у свідомості індивіда, його невтомному наближенні до досконалості дій у визначеній галузі, професії, спеціальності, спеціалізації, завданні, діяльності, операції, робочому русі. Зміни стаються в людини під впливом соціально-культурних стимулів, а також власної, свідомої та цілеспрямованої загальної та професійно зорієнтованої активності. У цьому процесі з'являються щораз форми вищого виду професійно зорієнтованої й професійної активності, як ряд змін, цілеспрямованих на творчий або відтворювальний контакт індивіда 3 матеріальною або соціально-культурною реальністю" ${ }^{5}$.

У процесі багаторічної праці над суттю професійного розвитку К. Чарнецький збагатив його визначення, зауважуючи, що зміни свідомості й поведінки індивіда $\epsilon$ ефектом взаємозалежного впливу об'єкта й суб'єкта, який проявляється у визначених формах соціально-культурної активності, у пошуках для себе місця, визначеного працею, у творчому вдосконаленні як себе, так і матеріального, суспільного й культурного середовища ${ }^{6}$.

Як видно, професійний розвиток це складний і довготривалий процес. Хоч поєднується, в основному, 3 етапом дорослості, але охоплює все життя, тому що вже на перших щаблях освіти має місце професійна профорієнтація. Цей процес також зумовлюваний багатьма чинниками.

\section{3. Зумовленості професійного розвитку.}

Відзначається дві основні групи чинників, що зумовлюють професійний розвиток: суб'єктивні й об'єктивні. До суб'єктивних чинників належать біологічні зумовленості, тобто генетичні зумовленості ознак організму, основний метаболізм, тип нервової системи, тип темпераменту, антропологічний i конституціональний тип, стать, фізичне здоров'я, вік. До цієї групи приєднуються теж фізичні зумовленості (зокрема правильності розвитку фізичних ознак організму та окремих органів, особливо тих, які є активними в процесі науки й праці), також і психічні, тобто суспільний досвід, цілеспрямовані дії, планування майбутнього.

Серед об’єктивних чинників вирізняються: зумовленості історичні (підготовка людей до життя, праці й захисту в усіх історичних і суспільно-економічних формах); економічні (рівень розвитку держави й перспективи, багатства країни, потреба в кваліфікованих кадрах), технічні (рівень розвитку техніки, міжнародне співробітництво, технічна зацікавленість суспільства, головне дітей і молоді); культурні (доробок народу й держави в різних сферах); суспільні (суспільна й приватна власність продукції, суспільні взаємини, соціально-культурне середовище, а також середовища: сімейне, шкільне, однолітків, професійне, суспільно-політичне); педагогічні (право на науку, шкільний обов'язок, система освіти, доступ до шкільних посібників і підручників, кваліфікація педагогічних кадрів, система психологопедагогічних консультацій, мережа спеціального шкільництва) ${ }^{7}$. Розглядаючи зумовленості професійного розвитку, потрібно брати до уваги, що це питання дуже складне й багатоаспектне, як і те, що чинники ці діють комплексно, у різних конфігураціях. Таким чином, важко визначити тут якусь ієрархію значимості. Однак з упевненістю належить наголосити, що в професійному розвитку вчителя, попри багато інших умов, особливу роль відіграє активність індивіда, як важливого суб'єктивного чинника. Зауважує це К. Дурай-Новакова, коли пише, що "людина розвивається психічно через активність, тому в градації зумовленостей активність займає центральне місце серед чинників розвитку" 8 .

4. Процес професійного розвитку.

Професійний розвиток - це процес, а отже, ряд певних змін. Проявляється в різних формах активності.

\footnotetext{
${ }^{4}$ K. Czarnecki, S. Karaś, Profesjologia w zarysie (rozwój zawodowy człowieka), dz. cyt., s. 62-64.

${ }^{5}$ K. Czarnecki, S. Karaś, Profesjologia w zarysie (rozwój zawodowy człowieka), dz. cyt., s. 27.

${ }^{6}$ K. M. Czarnecki, Profesjologia, Sosnowiec 2010, s. 35.

${ }^{7}$ K. Czarnecki, S. Karaś, Profesjologia w zarysie (rozwój zawodowy człowieka), dz. cyt., s. 69-93.

${ }^{8}$ K. Duraj-Nowakowa, Nauczyciel: kultura-osoba-zawód, Kielce 2000, s. 161.
} 
Соціально-професійна адаптація. Це пристосовування до професійної діяльності, до місця праці. Цей процес багатовимірний, в ньому можна виокремити адаптацію "суто професійну", психомоторну, фізичну й оздоровчу, суспільну, моральну, почуттєву, естетичну, культурну й політичну ${ }^{9}$.

Я. Якубовський виділяе психологічну, педагогічну, соціологічну й етичну адаптацію ${ }^{10}$.

У адаптаційному періоді важливу роль відіграє професійний старт, у якому з'являється конфронтація уявлень про професію з реальністю, розпізнавання нової ситуації, самовизначення в ній, як і долання різних труднощів, напр., емоційної природи.

Пристосованим до професії можна визнати вчителя, задоволеного працею, який висловлює бажання працювати далі, а не бажання змінити професію. Той вчитель визнає свою роботу як суспільно важливу.

Адаптація до професії - це об'єктивне явище, що з'являється на кожній новій роботі чи на новій посаді. Її перебіг залежить від підготовки вчителя до професійних завдань, від ступеня їх складності, також від умов, у яких вони виконуються.

Соціально-професійна ідентифікація. Означує ототожнення вчителя з власною професійною роллю. Ідентифікацію супроводжує, зазвичай, сильне емоційне налаштування, і також відчуття спільності 3 професійною групою, а особливо $з$ іiі цілями й цінностями. К. Чарнецький і С. Караш вирізняють: декларовану ідентифікацію - базується на мріях і уявленнях, акцептовану ідентифікацію - спирається на раціональне мислення і реалістичний погляд на професійну діяльність, реалізовану ідентифікацію грунтується на прийнятому щодо вибору професії рішенні ${ }^{11}$. У ході професійної діяльності найбільш бажаним є третій вид ідентифікації.

Можна також говорити про автентичну ідентифікацію, реальну, реалістичну, але також і про удавану, слабо усвідомлену й обгрунтовану. Остання з'являється, коли вчитель має труднощі в процесі ідентифікації, які можуть виникати з різних причин, напр., з невластивої мотивації до вибору професії.

Соціально-професійна стабілізація. Є наступним вищим ступенем професійної активності працівника, й означає "відносну стійкість його зв'язку з професією, робочим місцем, місцем працевлаштування" ${ }^{12}$. Вона $є$ проявом схвалення умов й очікувань щодо професійної діяльності. Та стійкість $\epsilon$, деякою мірою, відносною, тому що існують певні чинники, що спричиняють зміни на місці роботи. Нині особливо вчитель мусить бути відкритий до змін, характеризуватися творчим неспокоєм, що мотивує до пошуку нових рішень. Надто статичний характер стабілізації може вести до рутини, та навіть до професійного застою.

Процес професійної стабілізації зумовлюваний як внутрішніми чинниками (індивідуальність учителя), так і зовнішніми (умови праці, сфера завдань); їх сума визначає відчуття безпеки, яке $є$ підставою для стабілізації й умовою хорошого функціонування вчителя в професії.

Перепідготовка, удосконалення й соціально-професійне самовдосконалення. Виникає 3 професійних прагнень учителя і з вимог праці. Доповнення, збагачення й поглиблення професійної кваліфікації сприяє поліпшенню якості роботи, а також є джерелом особистого задоволення вчителя. Активність, спрямована на перепідготовку й вдосконалення, хоч і вимагає чималих зусиль, тому що проходить паралельно з реалізацією професійних обов'язків, але $\epsilon$ на сьогодні необхідністю, тому що неперервне навчання властиве професії вчителя ${ }^{13}$. Професійне вдосконалення має ефект погляду в себе, у власну професійну діяльність. А таке вміння повинно характеризувати вчителя. Серед багатьох потрібних елементів підготовки до праці K. Denek виділяє, посилаючись на Р. Й. Югера й М. ХендриксаЛi (R. J. Yiuger i M. Hendricks-Li), і те, що вчитель має бути рефлексійним практиком, який постійно оцінює ефекти своєї праці; у ії різних сферах, а також активно шукає нагоди до професійного розвитку ${ }^{14}$.

Рівень рефлексії й саморефлексії вчителя різний на окремих етапах професійного розвитку. У вчителя-початківця спостерігаємо початки цього процесу. Досвід, якого з часом він набуває, веде до саморефлексії, до поглиблення професійної свідомості ${ }^{15}$. Рішення про перепідготовку й професійне

\footnotetext{
${ }^{9}$ K. Czarnecki, Rozwój zawodowy człowieka. dz. cyt. s. 153-163; K. Czarnecki, Rozwój zawodowy człowieka dorosłego, "Oświata Dorosłych" 1985b, nr 6 s. 331-332.

${ }^{10}$ J. Jakóbowski, Zarys teorii rozwoju zawodowego nauczyciela, Warszawa 1987, s. 72-87.

${ }^{11}$ K. Czarnecki, S. Karaś, Profesjologia w zarysie (rozwój zawodowy człowieka), dz. cyt., s. 145-147.

12 G. Paprotna, Stabilizacja społeczno-zawodowa jako przejaw rozwoju zawodowego nauczyciela (w świetle badań nauczycieli przedszkoli), "Nauczyciel i Szkoła" 1996, nr 1-2, s. 81.

13 G. Paprotna, Aktywność edukacyjna nauczyciela jako czynnik warunkujący rozwój zawodowy, [w:] Aktywność społeczna, kulturalna i oświatowa dorosłych, pod red. A. Fabisia i S. Kędziory, MysłowiceZakopane 2009.

14 K. Denek, Kwalifikacje nauczycieli w społeczeństwie opartym na wiedzy, [w:] Rozwój zawodowy nauczyciela, pod red. H. Moroza, Kraków 2005, s. 108.

${ }^{15}$ G. Paprotna, Autorefleksja w pracy nauczyciela, [w:] Kompetencyjny kontekst warsztatu pracy nauczyciela, pod red. P. P. Barczyka i G. Paprotnej, Mysłowice 2010, s. 164-167.
} 
вдосконалення часто $\epsilon$ результатом такої рефлексії. I хоч вчителі розпочинають професійне вдосконалення також через зовнішні збудники (формальні), але й у такому випадку потрібний рефлексійний підхід до професійних завдань.

Сьогодні межу між перепідготовкою, удосконаленням і професійним самовдосконаленням часто важко визначити, учителі, удосконалюючись, беруть участь у керованих формах цього процесу (що колись було пов'язане, швидше, з професійною перепідготовкою).

Соціально-професійна рекваліфікація. Здобування нових кваліфікацій з метою зміни професії, посади чи соціально-професійних повноважень - це ознака системи вільного ринку. Це явище стосується також і вчителів, які мусять таким чином реагувати на потреби власні й ринку праці. Легше проходить зміна кваліфікації молодшими людьми, старші мають більші втрати (час, фінансові ресурси, фізичні й психічні сили, відчуття особистої цінності) ${ }^{16}$. Чим старший працівник, тим важчою, а часом просто неможливою стає професійна рекваліфікація.

Соціально-професійні успіхи. Мають бути наслідком усіх проявів професійної активності вчителя. Можна їх досягати в різних сферах професійного життя. Потрібно розглядати їх у трьох аспектах: психологічному (успіх $є$ результатом цілеспрямованої й організованої діяльності вчителя), соціологічному (успіх означає кар'єру, підвищення, здобування щораз вищих посад і суспільного престижу) та педагогічному (успіх пов'язується з досягненнями в дидактично-виховній роботі) ${ }^{17}$.

Успіх є доволі індивідуальною категорією професійного розвитку, тому що кожен учитель трохи інакше визначає те, що для нього $є$ успіхом. Однак, особливо важливими $є$ тут дидактичні й виховні досягнення, тому що це вони свідчать про те, що вчитель визнаний як спеціаліст у своїй галузі. Можна сказати, що успіх має значення як в індивідуальному, так і в суспільному вимірах і $є$ підтвердженням професійної придатності вчителя.

Соціально-професійні успіхи, як вершинні досягнення в роботі, ведуть до професійної майстерності і $\epsilon$ водночас їх підтвердженням. Учитель досягає найвищого ступеня професійної кваліфікації, що проявляється досконалим виконанням завдань.

Поступовий регрес соціально-професійної активності. Означає поступовий спад психофізичних сил і мотивації до професійної діяльності. До цього спричиняє біологія людини, плин життя й розвитку. Учитель діє повільніше, часом трапляються у нього помилки, слабшою стає концентрація уваги й свіжість пам'яті, що впливає на якість результатів педагогічної праці. Отже, це поступове зниження професійної активності вчителя ${ }^{18}$. У цей період у свідомості вчителя з'являються думки про пенсію, про відпочинок. Він починає також усвідомлювати потребу в зміні поколінь, яка завжди має місце, у кожній професії. Рефлексійна оцінка професійної ситуації веде до усвідомлення "відстані", яка відділяє досвідченого вчителя від молодих початківців цісї професії.

Вихід із чинної соціально-професійної діяльності. Вихід на пенсію $є$ актом, до якого вчитель готується протягом певного часу. Для одних це сумна необхідність, інші приймають його $з$ радістю. Змінюється спосіб життя вчителя. Будує він певні плани, у яких часом $\epsilon$ ще місце для невеликого контакту з професією. Учитель на пенсії може проявляти активність в інших сферах, ніж педагогічна робота ${ }^{19}$. Учителі зазвичай розуміють роль активності в житті людини. Отже, вихід із професійної діяльності часто не означає припинення активності взагалі. Часом учитель намагається, хоч би у вільній формі, утримати контакт з середовищем праці, а часом шукає для себе нових просторів життєвої та суспільної активності.

Період ремінісценції й професійної рефлексії. Спогади про колишню професійну діяльність домінують у пенсійному періоді. Учитель повертається до своїх почуттів, професійних переживань, можна сказати, - знову переживає свою професійну роль. Пристосовується до нової життєвої ситуації, у якій не має вже примусу до роботи, але водночас закликає ці елементи свого професійного життя, що були одночасно й формувальні, позитивні, і прикрі. Така рефлексія може бути джерелом науки для молодших учителів ${ }^{20}$. Рефлексії і спогади стосуються однаково позитивних подій, як і прикрих ситуацій, які справили вплив на перебіг професійної діяльності вчителя.

Кінець професійного жсття пенсіонерів. Учителі, як і інші пенсіонери, втрачають фізичні й психічні сили, хворіють, часом відходять несподівано. У цей період домінуючими є спогади - у професійному й сімейному середовищі - пов'язані 3 особою пенсіонера i його працею, а також

\footnotetext{
${ }^{16}$ K.M. Czarnecki, Profesjologia. Nauka o profesjonalnym rozwoju człowieka, Sosnowiec 2016, s. 363.

${ }^{17}$ B. Żechowska, Sukces zawodowy i jego uwarunkowania, Słupsk 1978, s. 45-48.

${ }^{18}$ K. Czarnecki, S. Karaś, Profesjologia w zarysie (rozwój zawodowy człowieka), dz. cyt., s. 152-153.

${ }^{19}$ K. Czarnecki, S. Karaś, Profesjologia w zarysie (rozwój zawodowy człowieka), dz. cyt., s. 153-154.

${ }^{20}$ K. Czarnecki, S. Karaś, Profesjologia w zarysie (rozwój zawodowy człowieka), dz. cyt., s. 156.
} 
індивідуальністю. Можна сказати - часто пенсіонери живуть соціально-професійним минулим, тому що робочий час був дуже важливим періодом в їхньому житті ${ }^{21}$.

\section{5. Результати професійного розвитку.}

Професійний розвиток можна розглядати також в категоріях результатів. Ці результати можна віднести також до розвитку вчителя.

Отже, соціально-професійна зрілість означає розвиток соціально-професійної сфери у такий спосіб, щоб учитель був здатний до відповідального й влучного вибору, що трапляється в ході професійної діяльності. Розумова, суспільна і емоційна зрілість дозволяє аналізувати реальність - життєву й професійну. Важливим елементом цієї зрілості є спрямовані обдарованості, зацікавленість, захоплення та мотивація до дії ${ }^{22}$.

Соціально-професійні кваліфікації це повноваження, отримані перед вибором і в ході професійної діяльності. Це дуже складна категорія, у яку входять кваліфікації: фізичні й оздоровчі (потенціал енергії і здоров'я); психічні (психічне здоров'я і загальна ясність розуму); суспільно-моральні й політичні (громадянські позиції у ставленні до професії, роботи, завдань держави й народу); загально гуманістичні (співжиття, співпраця, відповідальність за життя власне й інших); професійно-спеціалізовані (теоретична і практична підготовка до ефективної реалізації професійних завдань) ${ }^{23}$. Ці кваліфікації $є$ результатом професійного розвитку, але багато з них мають також характер процесу.

Соціально-професійна придатність $є$ результатом адаптації, стабілізації й професійної ідентифікації. Означає "адекватну підготовку до роботи відповідно до вимог робочої посади, підтримувану мотивацією до виконання професійних завдань" 24 . Соціально-професійна придатність $є$ сумою всього, що вчитель робить професійно, з тим, як функціонує соціально.

Соціально-професійні успіхи це досягнення щораз вищих ступенів досконалості в професії. Вони $є$ як проявом, так і результатом професійного розвитку вчителя. $Є$ наслідком соціально-психічної зрілості і охоплюють досягнення у сфері професійної діяльності та ширше - у позапрофесійній діяльності. Усупереч уявленням - вони пов'язані, бо професійний успіх необхідно визнати суспільним успіхом. Виникає це, між іншим, із суспільного характеру праці (особливо вчителя) ${ }^{25}$. Соціально-професійна індивідуальність - це ознака індивідуальності як людини, і як вчителя. Це комплекс багатьох розпоряджень, ознак, умінь, положень, які свідчать про відповідне професійне функціонування ${ }^{26}$. 3міст і характер професійної діяльності впливають на формування професійної особистості. Це структура, що формується в процесі професійної підготовки, розвивається й фіксується в ході професійної діяльності ${ }^{27}$.

Потрібно підкреслити динамічний характер особистості вчителя, це означає, що вона не $є$ чимось сталим і незмінним, але чимось, що створюється ${ }^{28}$.

Професійний розвиток вчителя можна також розглядати у світлі концепції професійного зростання. У 1999 році, разом з реформою шкільництва, введено в Польщі ступені професійного підвищення для вчителів. Принципи клопотання про наступні ступені регулюють юридичні акти. Ступені підвищення це: учитель-стажист, контрактний учитель, штатний учитель, заслужений учитель.

\section{6. Професійний розвиток і загальний розвиток вчителя.}

Професійний розвиток тісно пов'язаний із загальним розвитком вчителя, бо охоплює він усі сфери особистості, яка є своєрідним "знаряддям праці". Водночас знання, уміння й досвід, які здобуває вчитель протягом професійної діяльності, не залишають без впливу його функціонування у сферах позапрофесійного життя. Професійний розвиток також зумовлюється властивостями розвитку окремих сфер, визначаючи напрям вибору професії й перебігу професійної діяльності (напр., тип темпераменту, здібності, і т.п.). Зв'язки цього типу свідчать про те, що процес професійного розвитку має бути пізнаваний як багатоаспектний, у всій своїй різнорідності й складності заразом.

Професійний розвиток, як зазначає автор теорії місця й простору - К. Чарнецький, "є однією $з$ інших категорій загального розвитку людини. Є він особливою категорією соціально-психічного розвитку, що має свої основи й тісні зв'язки 3 іншими категоріями, але водночас є тією категорією, яка окреслює виразно визначений, об'єктивно існуючий відрізок реальності, що заслуговує на виокремлення, старанне наукове пізнання й опис (...). Отже, які можна вирізнити зв'язки категорії загального розвитку? С їх

\footnotetext{
${ }^{21}$ K. Czarnecki, S. Karaś, Profesjologia w zarysie (rozwój zawodowy człowieka), dz. cyt., s. 159-160.

${ }^{22}$ K. M. Czarnecki, Profesjologia, dz. cyt., s. 163.

${ }^{23}$ K. M. Czarnecki, Profesjologia, dz. cyt., s. 169-170.

${ }^{24}$ K. M. Czarnecki, Profesjologia, dz. cyt., s. 202.

${ }^{25}$ K. M. Czarnecki, Profesjologia, dz. cyt., s. 175-176.

${ }^{26}$ G. Paprotna, Społeczno-pedagogiczne uwarunkowania funkcjonowania zawodowego nauczycieli przedszkoli, Kraków 2015, s.36.

${ }^{27}$ K. M. Czarnecki, Profesjologia, dz. cyt., s. 178-181.

${ }^{28}$ K. Duraj-Nowakowa, Nauczyciel. Kultura-osoba-zawód, Kielce 2000, s. 101.
} 
доволі багато, і вони різноманітні, одні більш, а інші менш стислі. Залежить це від виділених категорій і від розуміння суті професійного розвитку"22.

I далі автор пояснює зв'язки професійного розвитку з розвитком: біологічним, фізичним, розумовим, чуттєвим, суспільним, культурним, моральним, еротичним, психомоторним, естетичним і політичним.

Учитель повинен уміти брати відповідальність за власний розвиток. Повинен також оволодіти умінням самоосвіти. Тільки це дає йому шанс на слідування за цивілізаційним розвитком ${ }^{30}$.

Такий широкий погляд на професійний розвиток обгрунтований значною мірою тим, що сучасна школа стоїть перед багатьма суспільними й культурними викликами ${ }^{31}$. Здається це особливо істотним в часи швидкого темпу змін, які несе сучасна реальність. Самоосвіта означає, таким чином, відповідальність за власний загальний розвиток та за розвиток професійний.

7. Висновки. Професійний розвиток учителя - це процес, у якому він підлягає певним загальним правилам, напр., проходячи через особливі форми активності, однак з іншого боку - це процес дуже індивідуалізований, тому що кожен учитель має власну, неповторну індивідуальність і також свою життєву й професійну дорогу.

Сучасна реальність ставить перед вчителем ряд нових завдань. Швидкий темп змін у багатьох сферах життя, розвиток нових інформаційних технологій, зміни умов суспільного життя, - усе це створює нову ситуацію також і в педагогічній сфері. Важливим контекстом професійного функціонування вчителя стали також процеси інтеграції Польщі з Європою, на що звертає увагу П. П. Барчик ${ }^{32}$. У плануванні свого професійного розвитку вчитель мусить враховувати й цього типу зумовленості.

Необхідним чинником здобуття майстерності в професії $\epsilon$ власна активність учителя. Важливим $\epsilon$ й те, щоб наступні цілі, що ставляться в цьому процесі, учитель сприймав як власні, а не тільки нав'язані. Тільки так професійний розвиток буде автентичним, а не удаваним. Учитель, котрий не розвивається, не багато може запропонувати своїм учням, для яких має бути провідником. У цьому контексті турбота про освіту вчителя і про його розвиток має бути предметом суспільної зацікавленості.

Професійний розвиток вчителя, як процес дуже складний і зумовлений багатьма чинниками, $\epsilon$ предметом зацікавленості численних дисциплін і наукових субдисциплін, напр., педагогіки, педеутології, праксеології, професіології, етнографії, філософії. Ці науки, надаючи знання про людину, допомагають у поглиблений та інтегрований спосіб досліджувати й пояснювати явища, що мають місце в ході професійної діяльності, яка займає найбільший обсяг в професійній активності вчителя.

\section{СПИСОК ВИКОРИСТАНИХ ДЖЕРЕЛ ТА ЛІТЕРАТУРИ}

1. Barczyk P. P. Europejski wymiar edukacji a polska rzeczywistość / P. P. Barczyk // Szkoła wobec społecznych i kulturowych wyzwań globalizacji, pod redakcją. - W. Kojsa, Wydawnictwo Uniwersytetu Śląskiego w Cieszynie, Cieszyn 2003.

2. Barczyk P. P. Nauczyciel i oświata w kontekście integracji Europy / P. P. Barczyk // Problemy współczesnej pedeutologii. Teoria - praktyka - perspektywy, pod redakcją. - D. Ekiert-Oldroyd, Katowice 2003.

3. Czarnecki K. Profesjologia w zarysie / K. Czarnecki, S. Karaś. - Instytut Technologii Eksploatacji, Radom 1996.

4. Czarnecki K. Rozwój zawodowy człowieka dorosłego / K. Czarnecki. - Cz. II. "Oświata Dorosłych" 1985 b, nr 6.

5. Czarnecki K. Rozwój zawodowy człowieka / K. Czarnecki. - Instytut Wydawniczy Związków Zawodowych, Warszawa 1985a.

6. Czarnecki K. M. Profesjologia / K. M. Czarnecki. - Oficyna Wydawnicza "Humanitas", Sosnowiec, 2010.

7. Czarnecki K. M. Profesjologia. Nauka o rozwoju zawodowym człowieka / K. M. Czarnecki. - Oficyna Wydawnicza "Humanitas", Sosnowiec 2016.

8. Denek K. Kwalifikacje nauczycieli w społeczeństwie opartym na wiedzy / K. Denek // Rozwój zawodowy nauczyciela, pod redakcją naukową H. Moroza. - Oficyna Wydawnicza "Impuls", Kraków 2005.

9. Duraj-Nowakowa K. Nauczyciel: kultura - osoba - zawód / K. Duraj-Nowakowa. - Wydawnictwo Wyższej Szkoły Ubezpieczeń, Kielce 2000.

10. Jakóbowski J. Zarys teorii rozwoju zawodowego nauczyciela / J. Jakóbowski. - Wydawnictwo Uczelniane WSP, Bydgoszcz 1987.

11. Kapica G. Wspomaganie autoedukacji-wyzwaniem dla współczesnej szkoły i nauczyciela / G. Kapica // Wokół problemów kształcenia podyplomowanego nauczycieli ; pod redakcją M. Mnich, A. Budniak, G. Paprotnej,

\footnotetext{
${ }^{29}$ K. M. Czarnecki, Profesjologia, dz. cyt., s. 37.

${ }^{30}$ G. Kapica, Wspomaganie autoedukacji-wyzwaniem dla współczesnej szkoły i nauczyciela, [w:] Wokół problemów kształcenia podyplomowego nauczycieli, pod red. M. Mnich, A. Budniak, G. Paprotnej, Mysłowice 2008, s. 20-21

31 P.P. Barczyk, Europejski wymiar edukacji a polska rzeczywistość, [w:] Szkoła wobec społecznych i kulturowych wyzwań globalizacji, pod redakcją W. Kojsa, Cieszyn 2003.

${ }^{32}$ P. P. Barczyk, Nauczyciel i oświata w kontekście integracji Europy. [w:] Problemy współczesnej pedeutologii. Teoria - praktyka - perspektywy, pod redakcją D. Ekiert - Oldroyd, Katowice 2003.
} 
Wydawnictwo Górnośląskiej Wyższej Szkoły Pedagogicznej im. Kard. Augusta Hlonda w Mysłowicach, Mysłowice 2008.

12. Paprotna G. Adaptacja społeczno-zawodowa jako przejaw rozwoju zawodowego nauczycieli wychowania przedszkolnego (w świetle badań) / G. Paprotna // Adaptacja młodego nauczyciela w zawodzie, redakcja naukowa T. Wróblewska, Mazowiecka Wyższa Szkoła Humanistyczno-Pedagogiczna, Łowicz 1998.

13. Paprotna G. Aktywność edukacyjna nauczyciela jako czynnik warunkujący rozwój zawodowy / G. Paprotna // Aktywność społeczna, kulturalna i oświatowa dorosłych ; pod redakcją A. Fabisia i S. Kędziory. - Wydawnictwo Górnośląskiej Wyższej Szkoły Pedagogicznej im. Kard. Augusta Hlonda w Mysłowicach, Mysłowice - Zakopane 2009.

14. Paprotna G. Autorefleksja w pracy nauczyciela / G. Paprotna // Kompetencyjny kontekst warsztatu pracy nauczyciela, pod red. P. P. Barczyka i G. Paprotnej. - Wydawnictwo Górnośląskiej Wyższej Szkoły Pedagogicznej im. Kard. - Augusta Hlonda, Mysłowice 2010.

15. Paprotna G. Społeczno-pedagogiczne uwarunkowania funkcjonowania zawodowego nauczycieli przedszkoli / G. Paprotna. - Wydawnictwo Górnośląskiej Wyższej Szkoły Pedagogicznej im. Kard. Augusta Hlonda w Mysłowicach. - Wydawnictwo Akademii Ignatianum w Krakowie, Kraków 2015.

16. Paprotna G. Stabilizacja społeczno-zawodowa jako przejaw rozwoju zawodowego nauczyciela (w świetle badań nauczycieli przedszkoli) / G. Paprotna. - "Nauczyciel i Szkoła" 1996. - Nr 1-2.

17. Żechowska B. Sukces zawodowy nauczyciela i jego uwarunkowania / B. Żechowska. - Wydawnictwo Wyższej Szkoły Pedagogicznej, Słupsk 1978.

\section{REFERENCES (TRANSLATED \& TRANSLITERATED)}

1. Barczyk P. P. Europejski wymiar edukacji a polska rzeczywistość / P. P. Barczyk // Szkoła wobec społecznych i kulturowych wyzwań globalizacji, pod redakcją. - W. Kojsa, Wydawnictwo Uniwersytetu Śląskiego w Cieszynie, Cieszyn 2003.

2. Barczyk P. P. Nauczyciel i oświata w kontekście integracji Europy / P. P. Barczyk // Problemy współczesnej pedeutologii. Teoria - praktyka - perspektywy, pod redakcją. - D. Ekiert-Oldroyd, Katowice 2003.

3. Czarnecki K. Profesjologia w zarysie / K. Czarnecki, S. Karaś. - Instytut Technologii Eksploatacji, Radom 1996.

4. Czarnecki K. Rozwój zawodowy człowieka dorosłego / K. Czarnecki. - Cz. II. "Oświata Dorosłych" 1985b, nr 6.

5. Czarnecki K. Rozwój zawodowy człowieka / K. Czarnecki. - Instytut Wydawniczy Związków Zawodowych, Warszawa 1985a.

6. Czarnecki K. M. Profesjologia / K. M. Czarnecki. - Oficyna Wydawnicza "Humanitas", Sosnowiec, 2010.

7. Czarnecki K. M. Profesjologia. Nauka o rozwoju zawodowym człowieka / K. M. Czarnecki. - Oficyna Wydawnicza "Humanitas", Sosnowiec 2016.

8. Denek K. Kwalifikacje nauczycieli w społeczeństwie opartym na wiedzy / K. Denek // Rozwój zawodowy nauczyciela, pod redakcją naukową H. Moroza. - Oficyna Wydawnicza "Impuls", Kraków 2005.

9. Duraj-Nowakowa K. Nauczyciel: kultura - osoba - zawód / K. Duraj-Nowakowa. - Wydawnictwo Wyższej Szkoły Ubezpieczeń, Kielce 2000.

10. Jakóbowski J. Zarys teorii rozwoju zawodowego nauczyciela / J. Jakóbowski. - Wydawnictwo Uczelniane WSP, Bydgoszcz 1987.

11. Kapica G. Wspomaganie autoedukacji-wyzwaniem dla współczesnej szkoły i nauczyciela / G. Kapica // Wokół problemów kształcenia podyplomowanego nauczycieli ; pod redakcją M. Mnich, A. Budniak, G. Paprotnej, Wydawnictwo Górnośląskiej Wyższej Szkoły Pedagogicznej im. Kard. Augusta Hlonda w Mysłowicach, Mysłowice 2008.

12. Paprotna G. Adaptacja społeczno-zawodowa jako przejaw rozwoju zawodowego nauczycieli wychowania przedszkolnego (w świetle badań) / G. Paprotna // Adaptacja młodego nauczyciela w zawodzie, redakcja naukowa T. Wróblewska, Mazowiecka Wyższa Szkoła Humanistyczno-Pedagogiczna, Łowicz 1998.

13. Paprotna G. Aktywność edukacyjna nauczyciela jako czynnik warunkujący rozwój zawodowy / G. Paprotna // Aktywność społeczna, kulturalna i oświatowa dorosłych ; pod redakcją A. Fabisia i S. Kędziory. - Wydawnictwo Górnośląskiej Wyższej Szkoły Pedagogicznej im. Kard. Augusta Hlonda w Mysłowicach, Mysłowice - Zakopane 2009.

14. Paprotna G. Autorefleksja w pracy nauczyciela / G. Paprotna // Kompetencyjny kontekst warsztatu pracy nauczyciela, pod red. P. P. Barczyka i G. Paprotnej. - Wydawnictwo Górnośląskiej Wyższej Szkoły Pedagogicznej im. Kard. - Augusta Hlonda, Mysłowice 2010.

15. Paprotna G. Społeczno-pedagogiczne uwarunkowania funkcjonowania zawodowego nauczycieli przedszkoli / G. Paprotna. - Wydawnictwo Górnośląskiej Wyższej Szkoły Pedagogicznej im. Kard. Augusta Hlonda w Mysłowicach. - Wydawnictwo Akademii Ignatianum w Krakowie, Kraków 2015.

16. Paprotna G. Stabilizacja społeczno-zawodowa jako przejaw rozwoju zawodowego nauczyciela (w świetle badań nauczycieli przedszkoli) / G. Paprotna. - "Nauczyciel i Szkoła" 1996. - Nr 1-2.

17. Żechowska B. Sukces zawodowy nauczyciela i jego uwarunkowania / B. Żechowska. - Wydawnictwo Wyższej Szkoły Pedagogicznej, Słupsk 1978.

\section{Папротная Г. Профессиональное развитие учителя.}

В статье представлен анализ проблемы профессионального развития учителя. Профессиональная деятельность является важной частью человеческой жизни, которая дает возможность удовлетворить много потребностей, как духовных, так и материальных. Профессиональное развитие - 
это прочесс количественных и качественных изменений, которые позволяют приблизиться к совершенной деятельности в определенной отрасли. Этот процесс одинаково предопределяемый как субъективными, так и объективными факторами. На основании проведенного анализа обоснованно, что профессиональное развитие проявляется в таких формах активности, как:

сочиальнопрофессиональная адаптация, социальнопрофессиональная идентификация, сочииальнопрофессиональная стабилизация, переподготовка и самоподготовка, социальнопрофессиональное совершенствование, соичильнопрофессиональные успехи, постепенный регресс социальнопрофессиональной активности, выход из действующей социальнопрофессиональной деятельности, профессиональная реминисценция и рефлексия. Доказано, что профессиональное развитие является такой категорией развития учителя, которая полностью охватьвает его.

Ключевые слова: учитель, профессиональное развитие, профессиональная деятельность, профессиональный рост.

\section{Paprotna G. Teacher's Professional Development.}

Professional work is an important part of human life allowing of providing for many needs, both spiritual and material. Professional development is a process of quantitative and qualitative changes that allow us to approach the perfection of action in a given field. This process is conditioned by subjective as well as objective factors. Professional development manifests itself in such forms of activity as: socio-professional adaptation, socio-professional identification, socio-professional stabilization, further education and self-improvement, socio-professional improvement, socio-professional successes, gradual regression of socio-professional activity, withdrawal from active social and professional work, professional reminiscence and reflection.

The outcomes of professional development include: socio-professional maturity, socio-professional qualifications, socio-professional usefulness, socio-professional successes and socio-professional personality. Teacher's development can also be considered in terms of career advancement levels. In Poland, teachers apply for successive grades: a trainee teacher, a contract teacher, an appointed teacher, a certified teacher and an honorary professor of education. Professional development is a category of a teacher's development that engages their entire personality. At the same time, professional experience also determines the teacher's functioning in various areas of non-professional life. In this context, the teacher becomes the subject of multidirectional research, mainly professiology.

Key words: teacher, professional development, professional work, career development and advancement. 